\title{
The Impact of Corona Pandemic on Legal Protection of Jordanian Employee's Right to Salary and Its Extensions
}

\author{
Walid Al qadi ${ }^{1}$ \\ ${ }^{1}$ Faculty of Law, the University of Jordan, Jordan \\ Correspondence: Walid Al qadi, Faculty of Law, the University of Jordan, Jordan. E-mail: w.qadi@ju.edu.jo
}

Received: August 7, 2020

Accepted: October 29, 2020

Online Published: February 25, 2021

doi:10.5539/jpl.v14n1p114

URL: https://doi.org/10.5539/jpl.v14n1p114

\begin{abstract}
The topic of the study is of special importance, as it relates to the source of public employee income and contemplates unusual events imposed by the Corona pandemic; Led to multiple preventive measures being taken to counter them; including the validity of the emergency defense law, which has multiple effects at all levels. To address negative economic conditions, administrative decisions were issued by the Cabinet against employees, which led to a reduction in their salaries and benefits. Hence, the study problem arose. Because it was not issued by the authority specified by the Defense Law which gives this authority to the Prime Minster, and accordingly many decisions exceeded its established legal rules and specific constitutional texts. The study aims to shit light on many aspects pertaining to the legal protection of Jordanian employee's right to salary and the basis on which the administration can modify it? We reached a set of results, most notably: The validity of the Defense Law specifically gives the Prime Minister, and not the Cabinet, the power to take exceptional measures to face the exceptional circumstance, by invoking exceptional legal rules stipulated by this law and not on the ground of the Civil Service Regulation. The most important recommendation was to cancel the new amendment of Article (193) of the Civil Service Regulation in line with the rule of legislative progression, as it contradicts the defense law and constitutes a violation of the constitutional provisions.
\end{abstract}

Keywords: organizational relationship, overtime, incentives, Jordanian defense law

\section{Introduction}

Public officials are those who express the will of the state, for being a public moral person. It cannot exercise its functions, implement its programs and translate its policies in providing public services to citizens except through them. Despite the tremendous technical development, the employee is still the backbone of the administrative apparatus, and the router of technology. Without him, they turn into rigid and ineffective tools. Given the importance of his tasks, the modern job systems have organized an integrated relationship with the administration within the framework of the principle of legality, in a manner that ensures the realization of the interest of work and the interest of the employee at the same time.

Out of this importance, this study comes to shed light on the most important right of the public employee, which is represented by the salary and its benefits. The importance of this study increases by knowing the legal protection of this right, especially with the issuance of some contemporary decisions that led to the violation of it, because of the negative economic effects caused by the Corona pandemic.

With the existence of the grave danger that threatens the entity of the state and the safety of the people that cannot be pushed back by the regular legal rules, the state has taken exceptional preventive measures to confront the Corona pandemic in various social, economic, security and legal fields, including the defense law. It is an exceptional law aimed at facing the exceptional circumstance, so some public facilities have been disrupted in providing the usual services, as exceptional decisions were issued to close down ministries and government institutions. The private sector stopped production due to the total curfew sometimes, and the partly at other times. The problem of the study emerged with the issuance of administrative decisions to address the effects of the negative economic consequences of the pandemic, which led to the reduction of the salaries of employees without relying on exceptional legal rules without having the competence or authority, which violates the principle of gradual legislation and the provisions of the constitution. 
Controversy arose over the legal protection of a public employee's right to his salary and benefits as well as the legitimacy of the administration's right to amend the employee's legal status. Does this right differ under exceptional circumstances from the ordinary? Does the employee's salary extend to include his job allowances and benefits?

Accordingly, we will rely in our study on the comparative descriptive analytical approach based on the analysis of legal texts and judicial rulings as well as the reference to jurisprudence opinions related to the subject of the study by dividing its plan into three topics and a conclusion that includes the most important results and recommendations.

\section{Nature of the Public Employee Relationship with Administration}

In order to take note of the legal protection of the employee's salary; It should be determined who is the person who acquires the status of public employee, the legal basis for regulating his duties and job rights with management; Based on this, we will divide this topic into two parts. In the first, I'll be addressing: the concept of public employee, and in the second: the adaptation of the functional relationship between the employee and management.

\subsection{Concept of Public Employee}

Undoubtedly, most functional laws and regulations did not lay down a comprehensive definition to the concept of public employee, even though they had specified the respondents in its provisions, as the definition differs from one legislation to another within the same country, because it is affected by the prevailing legal, economic and political systems, in addition to the evolving nature of the administrative law that requires no specific definition is recognized in the job systems. Therefore, the legislator has left to the administrative jurisprudence and judiciary a wide scope to define the concept of public employee.

In fact, the job legislation in Jordan has been greatly affected by the past French job legislation. For example, the French legislator in Article 1 of the legislation No. (2294) dated October 19, 1946 stated that: "Its provisions apply to people who are appointed to a permanent job, and hold a degree of staff in one of the central departments of the state, or one of its external facilities, or in national public institutions (André de laubadére,1953). This is what the Jordanian legislator has adopted, where the (CSR) Civil Service Regulation No. (9) of 2020 enshrines the applicability of this system to all civil servants, and to the employees of any public official institution that does not have a special system regulating the affairs of its employees. The third article of (CSR) stipulates that: "Despite what is mentioned in any other system, the provisions of this system apply to the employees of the departments whose jobs, grades and salaries are listed in the table of job formations issued under the General Budget Law or the Law of Government Units Budgets or the budget of any of the other departments." The reason for this is because the functional affairs of some employees are organized in accordance with special regulations or laws, such as judges, the military, policemen, and others.

Article 98 of the Jordanian constitution states that: "Judges of the Civil and Sharia Courts shall be appointed and dismissed by a Royal Decree in accordance with the provisions of the laws." Article 127 of the Constitution states that: 1- " The manner of recruitment to the Army, its organization and the rights and duties of its personnel shall be defined by a law. 2- "The organization of the police and gendarmerie and their competence shall be defined by a law". Also, members of the diplomatic corps, employees of the Royal Court, Parliamentary Councils, and employees of decentralized administrative bodies are subject to their own regulations. So, there is a special system for municipal employees (Regulation No. (108) of 2007), another for employees of the Social Security Corporation (Regulation No. (98) of 2008, a system for radio and television employees (Regulation No. (48) of 2008), a system for faculty members at the University of Jordan (Regulation No. (106) of 2007), and a system for employees of the University of Jordan (Regulation No. (33) of 1997)... etc

It is noted that the Jordanian legislator followed the French legislator's approach, which excludes some groups that have laws of their own; like the army and the judiciary (Mohsen Abdallah, 1997).

However, the Jordanian legislator gives the executive authority the right to issue regulations to regulate personnel affairs. Article 120 of the Constitution provides that the appointment and the dismissal of the employees and the limits of their powers and competencies shall be determined by regulations issued by the Council of Ministers with the approval of the King. The Supreme Administrative Court (Judgment No. 198/2019, dated 23 January 2019) ruled that: "The interpretative decision No. (2 of 2014) issued by the Constitutional Court ... included the interpretation of the text of Article (120) of the Constitution that the content of the text of this article is a dedication to the independence of the executive authority and to preserve the employee's attachment to it as it is the one that issues regulations that The legal status of the employee is determined ..."

So the organization of public office in Jordan is carried out by regulations and not by law, unlike the French 
lawmaker who made the job legislation take place by law; However, these regulations have a legal value equal to the regular laws, and this is what the judiciary affirmed: "This text is in line with Article (63) of the Civil Service Law No. 22 of 1966 issued in accordance with Article (120) of the Constitution ... which it has the power of law." (Supreme Court of Justice No. 21/1985, 1/1/1985).

The Article 76 of the constitution stipulated that: “... it is not permissible to combine membership of the Senate or House of Representatives with public office. The public office means every job whose holder takes his salary from public funds ...." But the judiciary confirmed: "Article (76) of the constitution was not laid down to define a public employee, but it meant from describing public employees those who are not permitted to combine membership of the National Assembly and the public job; therefore this text is not considered to include all public employees. (Supreme Court of Justice No. 9/75).

The legislator was aiming not to violate the principle of separating the three powers, and to remove the members of the National Assembly from suspicion so that they could monitor the executive authority as they represent the legislative authority and not others.

Article (169) of the Penal Code No. (16) of 1960 stipulates that: "Any employee in the administrative or judicial corps, every officer of the civil or military authority or any of its members and every employee in the state or in a public administration is considered a public employee. This expansion of the concept of a public employee is intended to protect public facilities and guarantee their workflow regularly (Nawaf Kanaan, 2019).

So the legislator included in the framework of public employees those who are not as such as workers in the private sector and private associations with public actions. Its aim was to expand the personal scope of criminalization, in order to give importance to the role of employees. Its course of action has not been successful. Where the term public employee was taken out of its traditional meaning (Majed El-Helou, 2006), but I believe that this definition is nothing more than it has defined the persons subject to its provisions in order to protect public funds, and therefore it is not considered a general and comprehensive legislative definition.

It is worth noting that the consecutive civil service regulations have included definitions for the public employee, the last of which is Regulation No. (9) of 2020, as it defined it as: "The person appointed by a decision from the competent authority, in a position included in the job formation schedule issued under the General Budget Law or the budget of one of the departments, and the employee appointed under a contract. This does not include the person who is paid daily.

We also find that the text of the first article of French legislation No. (2294) has indicated the elements that must be met for acquiring the status of a public employee, namely that the position is permanent, that the employee's service be in a public facility of the state. The successive French laws do not add new conditions to these except for the public position being occupied full time (Mohamed Hassanei, 1997) As Article (2) of Law No. (16) of 1984 stipulated that: "The provisions of this section apply to persons appointed full time to occupy a permanent position". The job according to the French system is that it is a permanent job in a profession that the employee joins from the beginning of his work until the end, meaning that it is permanent (Alain Plantey, 1971).

This is referred to by the definition of a public employee in Jordanian legislation, where three conditions are required that must be met in the person to be considered a public employee, namely: that the appointment be issued by a decision from a competent authority, that the job occupied by the employee is included in the schedule of job formations, issued according to the General Budget Law of the State, or according to one of the budgets of independent government units, and that the employee occupies a position in the service of an administrative public facility that is administered directly by the state or one of its legal persons. Based on this, workers in facilities managed in a concession manner are not considered public employees.

The jurisprudence and the administrative judiciary almost agree on these conditions, and add a condition that the legislator did not require, namely that the position be permanent. This is what the French State Council used in its provisions; Where it ruled that the public employee is "the person who is entrusted with a permanent position within the staff cadre, and is in the service of a public utility", (C. E, 9/3/1923, Hardouin, delaforge) and it decides that he is considered a public employee every person appointed in a permanent position affiliated with one of the cadres of the public utility (C. E, 20/12/1945, V. marcel Piquemal, 1973). It is the same position as the Jordanian judiciary, where the Supreme Administrative Court ruled that the public employee: "He is the person who is entrusted with permanent work in the service of a public utility managed by a person of the public law. This definition applies to utility employees run by the state represented in its three legislative, executive and judicial powers. It also applies to employees of public administrative institutions and institutions deemed to be persons of common law" (Ruling No. 49/2017, dated 02/22/2017). 
As for the most prominent doctrinal opinions that attempted to define the public employee, we find Waline; he defines it as: "Every person is appointed to a permanent position within a degree of the cadre of management and contributes to the management of a public facility that is managed by direct use" (Waline Marcel, 1959).

De Laubadere defines it as: "The person who takes a permanent position within the staff of the public utility" (André, De laubadere,1982), and finally the jurist Plantey defines it as: "The person who is appointed to a permanent position to contribute to the management of an administrative public facility" (Plantey, 2001). In Jordanian jurisprudence, it is defined as: "Every person entrusted with permanent work in the service of a public facility run by the state or a common law person (Hanna Al-Nada, 1972).

We can define it as: The person appointed by the competent authority to perform permanent work in the service of a public facility that is managed in a central or decentralized manner, and receives a salary included in the table of job formations in the state's general budget or one of the budgets of independent government units.

\subsection{Adapting the Functional Relationship between the Employee and the Administration}

Determining the nature of the job relationship between the employee and the administration is extremely important to clarify the duties and obligations that he must perform for the administration in exchange for obtaining his material rights as his right to salary, and moral as his right to promotion. Also it has importance in determining the applicable law, and the judicial authority to which he resorts in the event of any conflicts with the management.

There have been many theories describing this relationship, as there are a number of contractual theories, unanimously agreed that the relationship is of a contractual nature arising from the contract concluded, and a theory holds that the relationship is of an organizational nature. In fact, the two contractual theories, whether the one that adapts the relationship between the employee and management as a contractual relationship subject to the provisions of private law or the other that sees it as a contractual relationship subject to the provisions and rules of public law, have become almost abandoned theories, and are no longer accepted to adapt the employee's relationship with the state (Mahmoud Habib, 1998); Because the obligations that the public job entails for both the employee and the administration, such as the employee's commitment to obedience and loyalty to the job and the administration's commitment to fulfilling the employee's rights, as well as the protection that he enjoys while carrying out his job duties, cannot be interpreted as the result of a contractual relationship. (Ahmad Al-Sulaiti, Promotion of the Public Official in Qatar, Dar Al-Nahda Al-Arabia, Cairo, 2005, p. 46.)

Since these theories are an obstacle to which the principle of the continuous functioning of public facilities collides regularly (Esmat El-Sheikh, 1999), and leads to the failure to recognize the right of management to amend the legal position of the employee to achieve the public interest (Ramadan Batikh, 1997), jurisprudence has moved towards organizational theory. The idea that the public employee is in an objective legal position not a personal position is no longer a general idea only, but it has become a general, recognized principle. The thanks to the creation of this principle are due to the jurisprudence, which was able to liberate the public job system from the control and influence of civil ideas. Accordingly, those ideas became a form of the past (Abdul Hamid Hashish, 1974). So jurisprudence unanimously agreed to adapt the relationship between the administration and the employee as an organizational relationship (Asim Ajila, 1980), and it contains that the provisions of the public job and the rights and obligations that follow it are regulated in accordance with the regulations and laws (Ramadan Batikh,1997) This means that the position of the employee is organizational (Cornu (G), 1951), and then the appointment decision issued by the competent authority does not create a self-centered position for the public employee, because this position is already present before the appointment decision, and it is based on laws and regulations in general, not personally (Rolland, 1953).

This adaptation has multiple consequences, perhaps the most prominent of which is; The decisions issued against public employees are considered administrative decisions (Suleiman Al-Tamawi, 1992) subject to the provisions of the administrative law, and accept the appeal for cancellation if they violate the laws and regulations (Muhammad Karaj, 2002), as well as the administration has the right to amend the rules of the public office because it has the power of the public authority.

The French State Council was the first to say this relationship, after which the French legislator confirmed this vision when it codified it in the Employment Law issued in 1946 (Sherif Khater, 2007), where the provisions of the State Council stipulated that the employee's relationship with the administration is organizational (C. E. 24 / Nor / 1916 Baron Rec.), and ruled that the administration has the right to modify the status of the public employee without arguing that he has acquired rights. (C. E. 12/24/1937, Bigne de villeneure.)

As for the Jordanian legislator, it did not explicitly stipulate this relationship, but it implicitly referred to it and acknowledged that the legal status of the public employee is organizational. Article (2) of the Civil Service 
Regulation No. (9) of 2020, stipulates that the job: "A set of tasks and duties determined by a competent authority and entrusted to the employee to perform them in accordance with the provisions of this regulation and any other legislation".

The interpretative decision No. 2 of 2014 of the Constitutional Court included an explanation of this relationship. It explained that the executive authority is the one that issues the regulations that determine the legal status of the employee. The Supreme Administrative Court ruled: "The employee's relationship with the state is an organizational relationship governed by laws and regulations issued in this regard" (Ruling No. 205/2017, 4/7/2017).

The bottom line is that adapting the employee's relationship to management as an organizational relationship leads to the activation of the principle of legality, because laws and regulations regulate public job affairs. Therefore, the public interest of good public facility and the right of management to amend the functional legal positions on the one hand, and provide legal protection for the employee on the other hand, are realized.

\section{Employee's Right to Salary and Its Extensions}

The organizational relationship results in the employee obtaining multiple rights, the most important of which is his right to salary. What is meant by salary? What are its types and benefits?

\subsection{Concept and Definition}

At first, it must be noted that the salary extends to include the basic salary and the gross basic salary, which is known as the gross salary. This is what the Jordanian legislator covered in the civil service Regulation No. (9) of 2020 , as the second article stipulated that: “... the basic salary is the monthly salary due to the employee and receives in return for performing his duties in the position he occupies and does not include bonuses of any kind. Gross basic salary is the basic salary plus the cost of living allowance. Gross salary is the gross basic salary plus the monthly allowances all specified in accordance with the provisions of this Regulation.

An opinion in Jordanian jurisprudence went on to say: "The Jordanian legislator defined the salary in the civil service regulation as: the basic monthly salary that the employee receives in return for performing.... This definition is critical, because it did not highlight the basic element in the salary, which is the financial compensation he receives from the state treasury and does not show the intended meaning of the definition of salary, in addition to that it does not agree with the principles of legal wording which require that something is not defined with its like" (Ruling No. 205/2017, 4/7/2017). However, we believe that this criticism is under consideration, for it is valid even with regard to the fact that it is not permissible to define something with its like; But it is not correct in its content; Because what is meant by the salary is the gross basic salary and not the basic salary criticized by the holder of this opinion. Also, the basic element of the salary is not a financial compensation but cash compensation, because the term public money is more general and more comprehensive than the term monetary amount. All things that a person owns of money, real estate, furniture, vehicles, etc. are included under it. Money may be transferred or real estate, and is defined in Article 53 of the Jordanian Civil Law as: "Every property or right has a material value in dealing." In addition, the holder of this criticism did not set a jurisprudential definition of salary.

It is noted that some in Jordanian jurisprudence used the word: (money) when defining a salary; Where one of them defined it as: the financial compensation that the employee receives from the state every month in exchange for the work that he performs. The total monthly salary usually includes the basic salary and the sum of the bonuses added to it (Suleiman Batarseh, 2017). Another defined it as: the financial compensation that the employee receives periodically and regularly in return for what he does while serving in the public office (Muhammad Al-Khalayle, 2017).

These definitions are to blame for the salary being in exchange for the work performed by the employee during his service; Because the salary is not considered in exchange for work in absolute terms, the employee may receive his salary while he is suspended from work, in addition to carrying out the job tasks that are the duties of the employee. If he does not do so, he will be subjected to disciplinary sanctions for breaching his job duties.

The salary is in exchange for the employee's devotion and being free to employment, and is considered a means that allows him to maintain his social position. (Mohamed El-Desouky, 2006).

As for Arab jurisprudence, the salary was defined in a more indicative sense of its meaning. Where it is defined as: the amount that the employee receives periodically in exchange of his dedication in the service of the administration (Hamada Shata, 1977).

So, the salary is the monetary compensation that the employee deserves periodically in exchange for his dedication and devotion to his job, which is consistent with the interpretation of the Constitutional Court; It considered that: 
"Determining the employee's periodic salary is done in exchange for his full-time job assignment and not to perform any other work" (Supreme Administrative Court Judgment No. 198/2019, dated 23 January 2019)

\subsection{Types of Salary}

It has already been said that the Jordanian legislator has stated that the salary has several divisions; it is the basic salary, the gross basic salary and the gross salary. These divisions differ from each other, but they collectively constitute the salary of the public employee, and I address them as follows:

\subsubsection{Basic Salary}

The basic salary is the salary of the employee who receives it every month as a right to meet his full time devotion to his job without adding any bonus or other benefit.

There is no doubt that the salary of the public employee is determined in advance in the laws and career regulations, according to his job title, for being in a general organizational center. The job title means: The name specified for each job according to the qualifications of its employees, conditions of occupation, categories, grades, tasks of their occupants and their duties. This is what the legislator explained in Article Two of the current civil service regulation. This category means: A set of jobs with specific grades, salaries, specifications and responsibilities (Article (2), (CSR) Civil Service Regulation No. (9) of 2020).

The legislator also determined in Article 19 of the (CSR) the levels, grades, basic salaries and the annual increase for the employees of the first, second and third categories according to the salary scale referred to in the civil service regulation. As for the employees of the higher category, which are divided into two groups, their basic salaries, representation allowance and other allowances were determined through legal texts, and without setting their salary scale.

The employee deserves his salary from the date he commenced work, and gets paid from his job allocations that he actually occupies, which are monitored in the table of job formations in the state's general budget or one of the budgets of independent government units.

It is worth saying that the legislator stipulated the annual increase in the basic salaries in the articles related to the basic salary, and included it in the salary scale for the first, second and third categories. The value of the annual increase in the employee's salary varies according to the category and the degree that he occupies. It is determined by an amount of (25) dinars for everyone who occupies any of the second group jobs within the higher category; Calculated from the date of appointment. The employee under trial is entitled to it if his appointment has been at least eight months.

The entitlement to the annual increase in the basic salary shall be on 12/31 of each year for someone who has spent an actual year in service, unless a decision is issued to withhold it, and in other cases prescribed by the legislator, such as the employee obtaining during the service a higher educational qualification than his current qualification ... etc. (Articles (30, 33 and 34 of the CSR)

The annual increase in the basic salary is known in France as the salary promotion system (André de Laubadére, 1982) stipulated by the Public Service Law of 2006 (Serge Salon, 2006), and its effect is limited to increasing the employee's salary (André de laubadère, 1982). It is reached according to the period of service in the administrative scale (Alain Plantey, 1963). It is called in Egypt the periodic allowance (Anis Jaafar, 2007); for being used as an incentive to the staff. With the correctness of this trend, the Jordanian legislator did not use this term, he did not say a basic allowance as it was called by some Jordanian jurisprudence (Nawaf Kanaan, 2019, Muhammad AlKhalayleh, 2017) and did not stipulate it within the articles related to allowances, but rather explicitly stated it in the articles related to the basic salary.

So, the annual increase leads to an increase in the basic salary, whether it is related to the passage of the actual year of the employee's position in the job, or if it is due to one of the other reasons stipulated by the legislator.

\subsubsection{Gross Basic Salary}

The gross base salary is the same as the basic salary, but it is added to the cost of living allowance. Article (18) of the Civil Service Regulation stipulated the allowance without setting a definition for it, but he determined it. He made it for the employees of the second group in the upper category with an amount of (200) dinars per month, but for the employees of the first group, he decided for them this allowance as the allowance for the working minister. The employee gets in the first, second and third categories an amount of (135) dinars monthly as provided in Article (23) of the CSR.

As for the allowance of the high cost of living, it is defined in jurisprudence that it is an amount of money owed to the employee in addition to his basic salary to help him to face his social burdens. This allowance has no relation 
to the nature of the job, its difficulty, its duties or responsibilities, provided that the job is one of the permanent job groups (Badria Al-Saleh, 1994).

We see that it is a lump sum of cash, added to the basic salary of the employee according to the job category that he occupies. It aims to achieve decent and adequate living for him and help him in facing the burdens of life. Therefore, the gross basic salary represents the minimum for the public employee.

\subsubsection{Gross Salary}

Gross salary is the salary of a public employee represented by the basic salary, the high cost of living allowance, and all the monthly allowances that he entitles to, stipulated in the job regulations, which are an integral part of the salary.

In addition to the high cost of living allowance, the legislator stipulated other monthly allowances, which I will address as follows:

\section{A. Family allowance}

The family allowance is related to the employee's social condition. Therefore, it is only entitled to a person who meets one of its conditions, such as if he is married. If he is widowed or divorced, he must have children. Also, the female employee deserves it if her husband is crippled, or if she takes care of her children, or divorced if she does not receive a legal alimony for her children, provided that the children were no more than eighteen years old in all cases. The legislator set this bonus at an amount of twenty dinars, and did not take into account the number of family members of the employee.

\section{B. Additional allowances}

The additional allowances are multiple and varied. Each allowance is granted separately to the employee by the administration if he fulfills the conditions for any of them, and it is possible to combine them. They are represented by a cash amount calculated by specific percentages of the basic salary according to instructions issued by the Council of Ministers, and due from the date the employee commences his work. Among the most prominent are the technical bonus, supervisory bonus, enterprise bonus, job site bonus or any other bonus (See Article (25), of the CSR), such as transportation bonus and promotion bonus from one degree to a higher degree.

The Supreme Administrative Court indicated the meaning of the technical allowance when it ruled: "The petitioner occupies the position of a teacher in the Ministry of Education, the technical allowance for this position is a teacher bonus, and since he was transferred to the Ministry of Labor as an inspector, the technical allowance for this job is an inspector's bonus" (Ruling No. 205/2017, dated 4/7/2017).

It should be noted that the legislator excluded employees of the second group from the higher category. So, he decided to grant them a technical allowance of $(50 \%)$, and if the department granted its employees an institutional allowance, he deserves it (30\%) of the basic salary (See Article (18) of the CSR).

\subsection{Salary Extensions}

They are called job allowances. The allowance is a cash consideration that the employee deserves as a result of the additional burdens that negatively affect the adequacy of his salary, and which the employee incurs because of the job or its suitability (Muhammad Abu Yunus,1999). In different job systems, the type of allowance, its rules and conditions are determined. The matter of its determination is subject to the discretionary management authority, which is linked to the employee's performance, where he gets it if he fulfills its conditions. We will address these allowances as follows:

\subsubsection{Overtime}

The overtime is work that is an extension of the original work. The employee performs it in his workplace outside the specified official working hours, in order to accomplish job tasks that need more time (Ahmad Sharaf al-Din, 1983), in exchange for a cash allowance commensurate with his effort and additional time.

Article (28) of the CSR has determined this additional time by two hours or more in return for an amount of thirty percent of the basic salary, and this is done by issuing a decision to assign the employee by the concerned minister, in the following cases:

A. If the nature of the department's work requires the application of the shift system, so that the work continues (24) hours, such as working in hospitals and customs departments at border crossings and airports.

B. If the nature of the services of the department or any organizational unit in it requires additional work, such as the nature of the work of the income and sales tax department. 
C. If the department or the organizational unit has a seasonal work that must be accomplished during a specific period of time, and this is not possible during the normal official working hours or has an urgent work, for example, working in the Ministry of Interior and the Civil Status Department.

D. If the department has a program or project that requires additional work for the purposes of its follow-up and implementation, such as working in the Department of Statistics.

In the event that the financial allocations are not available; It is permissible to add a day off to the employee's annual leaves for every five additional hours of work, up to a maximum of ten days per year instead of cash dues. This allowance may not be combined with the day-to-day bonuses or rewards related to the period of overtime. The overtime payment is suspended when its justifications disappear, or the employee is absent for any reason or does not complete the work due to negligence or failure.

\subsubsection{Representation Allowance}

It is an amount of cash given to the employee in lieu of the expenses and costs incurred by him as a result of performing the work. It aims to the need for the employee to appear in a decent social appearance (Omar Helmy, 1994).

The legislator stipulated the representation allowance and referred to it sometimes as a reward. He decided that the employees of the first group in the higher category would receive the minister's privileges, while the employees of the second group as well as the employee appointed to head the council of anybody or authority, they deserve an amount not exceeding $50 \%$ of their total salaries as a compensation for representing the government in the boards of directors of Government institutions or companies in which it subscribes or in its management, provided that the meeting of any of them is outside the official working hours. Also, the employees deserves any reward or an allowance in exchange for his work outside the official working hours in other than his department, provided the approval of the competent authority. In the event that the sum of the rewards and annual allowances exceeds the specified percentage, it will be returned to the Treasury Department (See Articles (28) and (183) of the CSR).

\subsubsection{Material and Moral Rewards}

These bonuses are considered incentives, and are granted on the basis and conditions according to instructions issued by the Council of Ministers, including moral ones; such as the ideal employee award and the Order of Excellence received by the most qualified employee (See Article (34)of the CSR), and material; such as financial incentives that should not exceed the total employee salary (Article (29 of CSR), such as those of doctors and pharmacists; Where they are paid incentives every three months, (See Article (7), Doctors and Pharmacists Incentives Regulation No. 32 of 1992) and the rewards of the employees of the Income and Sales Tax Department (See Article (76), Income Tax Law No. 34 of 2014) and other employees.

It is noted that the Jordanian legislator in the income tax law considered taxable the total income derived from the job, whether it is in the form of salary, bonus, reward, allowances or any other privileges. The personal exemption is set at 9 thousand dinars, as a result of that, any employee who receives a total salary of more than 750 monthly is subject to tax, which is progressive starting at $5 \%$ for the first five thousand dinars, and for every five thousand dinars, followed by an increase in the percentage until it reaches $25 \%$ (See Articles (3), (9) and (11)).

\section{Guarantees of the Employee's Right to Salary and Its Extensions}

The employee's right to salary is one of his most important job rights, because it constitutes a major source of his income and livelihood. As a result, no person can accept to occupy the job without consideration. Based on this importance, the legislator has conferred legal protection on this right in the form of several guarantees, including: The employee should not be deprived of the salary in whole or in part, except under certain conditions, and he has the right to challenge the administration decisions related to the amendment of the salary and its extensions.

\subsection{Employee not Be Deprived of the Salary in Whole or in Part}

The legislator decided not to deprive the employee of the salary in whole or in part, and this is what we will address in two consecutive branches, as follows:

\subsubsection{Employee is not Totally Deprived of the Salary}

The legislator is keen on determining the minimum salary for the public employee, which is the total basic salary - which we covered in the previous topic. The employee deserves this salary at the end of each month in exchange for his full-time work and actual service performance, even if the method of performance varies; like remote work that existed due to the Corona pandemic. This rule has several exceptions. An employee may be entitled to his salary while he is out of work in the following cases: 


\section{1) Holidays}

The general principle is that the employee devotes himself to perform the work entrusted to him according to the dates specified by the competent authority. The employee is owned by the state, and accordingly, he may not stop work, except for a legal reason (Anwar Raslan, 1997), but the employee cannot continue to work at the same level of activity at all times; Therefore, he needs to rest to renew his activity, and as a result, all employment legislation sets times for official working hours. The Jordanian legislator in Article 97 sets them seven hours per day and for five days per week (Article 97 (A), of the CSR), meaning that there are two days per week during which employees do not work, in addition to the official holidays scheduled on the occasion of national and religious holidays.

Against the Corona virus pandemic, which invaded the world, a decision was issued on March 17, 2020 to suspend all institutions, official departments and courts from operating except for vital sectors, including education; where it became from a distance. In the same date, the royal will was issued by approving the decision of the Council of Ministers to announce the implementation of the Defense Law No. (13) of 1992, throughout the Kingdom (The Official Gazette, No. 5625, dated 3/18/2020.). The holiday lasted until the date of May 30, 2020, where notice No. (6) was issued according to the defense order No. (5) for all institutions to start their work (The Official Gazette, No. 5643, dated 27/5/2020.). The bottom line is that the holidays referred to above, including the vacation imposed by the Corona pandemic, do not affect the salaries, allowances, bonuses, and remuneration of employees, even though they do not work.

\section{2) Leave}

Leave of all kinds is a certain time period in which the employee stops his work, (Ramadan Batikh, 1997) as permitted by job legislation. The employee may be subject to sick, social or educational conditions that require him to stop working. Accordingly, the job legislation stipulates this right, which is positively reflected on the business. Where the employee regains his strength and is more active and devotes himself to perform the work as best as possible.

The French legislator stipulated the employee's right to obtain regular and sick leave, and granted the employee the right to take paid leave such as the right of a working woman to obtain a maternity leave for a period of fourteen weeks, and the right of an employee in contact with the patient with an infectious disease (Mohamed El-Desouky, 2006). Generally, the leave is a right for the public employee in France (Gustave Peiser, 2000).

In Jordan, the legislator in Article 98 of the CSR stipulated the employee's right to obtain multiple vacations, and requests the approval of the administration to grant it except for occasional leave, maternity leave and Hajj. It also decided to give the employee an annual leave of thirty days per year, a maternity leave for the employee ninety days, a paternity leave for the employee for three days, accidental leave of no more than seven days per year and a pilgrimage leave of 21 days, all paid with salary and bonuses. As for sick leave, the full basic salary and bonuses are paid for the first four months, three quarters of the basic salary and bonuses for the next four months, and in the event that he is not recovering, he deserves the full basic salary and bonuses for the last four months, so that the sick leave becomes a full year.

\section{3) Scholarships}

The employee, as provided in Article 120 of the CSR, may be dispatched by the administration for a scholarship for a period of more than eight months, or a course or scientific mission inside or outside the country, in order to raise the efficiency of the work in line with modern developments in the methods and means of work in various fields. He will be discontinued from work, yet he deserves his full gross salary for that period, with the exception of the supervisory allowance and site bonus. The minister may pay him a cash amount according to the transport and travel system (See Article (132) of the CSR).

\section{4) Suspension from work}

Suspension from work is a temporary preventive measure; It aims to stop the employee's hand from the tasks entrusted to him so that he does not practice any actions that may affect the course of the investigation (Naeem Attia, 1971). Although the employee does not work, he is only entitled to half of the salary, as the salary is the only way for the employee's family to face the burdens of life. Justice requires that it not be deprived of income just for accusing the head of the family, he may be innocent, and he did not refuse to work by his will, but was forced to do so. The Jordanian legislator in Article 157 of the CSR adopted a clear position on the employee who is convicted; where he decided not to recover the sums paid to him during the detention period.

During the period of his suspension from work, the employee receives $50 \%$ of his total salary and allowances for the first six months from the date of his suspension, and $25 \%$ of the remaining period. As for the employees of the higher category, the Council of Ministers decides to stop the employee who commits the behavior violation, and 
it is it who determines the percentage paid to him of his salary and bonuses (See Article (159) of the CSR).

It also entrusted the competent minister with deciding to suspend work for the employees of the three categories in several cases (Article (150), of the CSR), including: If he is referred from his department to the disciplinary council, the public prosecutor, or the court, and if his department is required to stop him from work under other legislation, or he is referred to the competent judicial authority in accordance with the provisions of the applicable financial system. The minister may also stop him if a complaint is filed against him at the Public Prosecution or the Court.

The judiciary established that: "The decision to arrest the employee is related to the case in which he is subject to behavioral prosecution, excluding the crimes he commits in the course of his private life without having any connection with the job behavior or duties (Supreme Court of Justice No. 414/94, date 12/7/1995). The Supreme Administrative Court also affirmed that: "Cases of suspension from the work is exclusively mentioned, and it is not permissible to burden legislative texts more than it can bear."

\subsubsection{The Employee is not Partially Deprived of Salary}

It means that the employee is not partially deprived of the salary. it is not permissible to withhold the salary or deduct from it except with certain conditions and specific proportions. The Jordanian legislator was keen in the implementation law to protect the employee and his salary. So he decided according to Article 22, 23, and 31 of the Law of Implementation No. (25) of 2007 "Not to imprison the public employee if he did not pay the debt he had owed to his debtor", and stipulated that: "It is not permissible to seize what the employees receive ... except by one third of the total of what they receive except for the prescribed expense. Any amount exceeding one third of the employee's salary and travel expenses is excluded from the withholding (Article (13/f /g), Public Funds Collection Law, No. (6) of 1952 and its amendments).

However, the legislator decided to deduct from the salary as a punishment that is imposed on the employee if he commits a functional or behavioral violation in multiple cases, stipulating that if the employee has exhausted his annual leave and his sick leave specified for a week, the day on which he is absent is deducted from his basic salary and allowances. But if he does not return to work immediately after his leave has ended without legitimate excuse, he is deprived of his basic salary and allowances for that period. If the absence period exceeds ten consecutive working days, he is considered to be losing his job, and his leaves of absence are deducted at the rate of one day's leave for every seven hours in which he is absent. If the employee is late for work or leaves his work before the end of the official working time by a total of one hour per month, a day of his annual leave is deducted, and if he exhausts his annual leave, that hour is deducted from his gross salary at a rate of one day (See Article (112), Civil Service Law No. (9) of 2020).

The legislator also stipulated a penalty of deduction not exceeding seven days if the employee committed a violation of the applicable laws, regulations and instructions, or violated the code of professional conduct (See: Article (142), of the CSR).

\subsection{Employee's Right to Appeal the Administration Decisions Related to the Amendment of the Salary and Its Extensions}

The general principle is that the administration has the right to amend the salaries of public employees; except this right is not absolute, but is restricted by several conditions, whether under ordinary or exceptional circumstances, and if the administration does not comply, then everyone with an interest may appeal the amendment decisions before the administrative court.

In the aftermath of the Corona pandemic, a decision was issued by the Cabinet that affected the salaries and its extensions, which negatively affected the living conditions of employees (Instructions for managing the Himat Watan Fund accounts issued according to Defense Order No. (4) of 2020), and controversy arose about the legality of this decision. Does the employee have the right to appeal it for cancellation?

To answer this question, we show, starting with the right of the administration to amend salaries and their extensions in: 1- and then clarify when the employee has the right to challenge the management's decisions for cancelation in 2, as follows:

\subsubsection{Right of Administration to Amend Salaries and Extensions in Ordinary and Extraordinary Times}

The administration has the right to amend the rules of the public office, among them the amendment of salaries and their extensions, whether in ordinary or exceptional circumstances for being the holder of the public authority, according to the requirements of the public interest, without this matter being dependent on the approval or refusal of the public employee. Although the amendment may lead to prejudice to his legal position (Majid Al-Helou, 
2006), the employee's legal position is a public center that the administration has the right to modify by its own free will and whenever it wants, but this right is restricted by two conditions:

Condition I: that the formal rules be respected, so that amendment is made by the same legal instrument that defines the position of the employee (Abd al-Hamid Hashish, 1974), and that the amendments are general, and abstract, so that they apply to all employees who have similar positions in accordance with the principle of equality between occupants of similar positions, and lead to protection of the weakest party in the functional relationship, which is the employee (Majed Al-Helou, 2006).

This is in normal circumstances, but in exceptional circumstances, the matter is different, because the constitutional legislator stipulated in Article (124) that: "If something happens that calls for the defense of the country in the event of an emergency, a law will be issued in the name of the defense law that gives authority to the person designated by the law to take the necessary measures and actions, including the power to stop the regular laws of the state to secure the defense of the country ...".

Article 2 of the defense law of 1992 stipulated that: "A. If something happens that calls for the defense of the country in the event of an emergency that threatens national security or public safety in all parts of the Kingdom or in a region thereof due to the occurrence of a war, or the spread of a pest or epidemic, the implementation of this law, is declared with a royal will issued upon the decision of the Council of Ministers.

Article 3 of the same law provides that:" A. The implementation of this law is entrusted to the Prime Minister to take the necessary measures and actions to ensure public safety and to defend the Kingdom without being bound by the provisions of the applicable regular laws". It also stipulated in Article 10 that: "Any text or legislation that violates any provision of this law and the orders issued pursuant thereto shall be suspended".

By analyzing the previous texts and applying them to the reality created by the Corona pandemic, it becomes clear to us that the administration, when the law of defense is in effect, must rely on exceptional legal rules to confront the grave danger currently posed by the Corona pandemic, because it cannot be pushed by the regular legal rules. The aim of activating this law is to provide a means to protect public health and improve performance to face this epidemic. Therefore the administration must rely on the defense law when it resorts to amending the legal positions of public officials to confront the economic crisis resulting from the Corona pandemic, because the defense law leads to the suspension of any text or legislation that violates its provisions. The decision must be issued specifically by the Prime Minister, and not by any person or other party, according to a defense order to counter the epidemic in order to defend the Kingdom and preserve the safety of the people.

Condition II: the amendment not taking effect retroactively, because the applicability of this amendment to the past leads to a waste of the rights acquired by the employee under the previous system. The new system does not apply to him, except with an immediate effect. As an exception to this, the amendment may apply retroactively if it is stipulated by the same legal instrument. For example, it is not correct to stipulate the retroactivity of the system through instructions for being a lower tool, meaning that an employee who has become at a certain level in the career ladder or who has become paid a salary, he remains adhering to these acquired rights in the event of a new system that would bring about changes in these levels or these salaries. Noting that this amendment if it entails financial burdens on the public treasury and achieved material extensions for employees, it applies from the date of its implementation, unless it stipulates otherwise. If the text is ambiguous, it is interpreted in favor of the public treasury pursuant to the primacy of the public interest over the private interest (Ramadan Batikh, 1997).

\subsubsection{Employee's Right to Appeal the Amendment of His Salary and Extensions in Ordinary and Extraordinary} Times

The employee has the right to appeal the decisions of the administration related to the amendment of his salary and extensions, whether this amendment is cancellation, reduction or suspension. He may file a cancellation lawsuit before the administrative court, dismissing the individual administrative or organizational decision that is not legitimate, within sixty days from the date on which he became aware (Article (8), Administrative Judiciary Law No. 27 of 2014.) The legislator stipulated in 5(A)-5 that: "A. The administrative court exclusively is competent to consider all appeals related to the consideration of all appeals related final administrative decisions, including appeals related to salaries, allowances, annual bonuses and increases and the rights due to public officials according to the legislation in force.

After accepting the case in form by the court, it is transferred for consideration by subject. It checks the legitimacy of the contested decision. If it becomes clear to it that the decision is identical to the law, then the lawsuit is rejected, because the decision is true, legitimate, and free from defects of cancellation. The administrative decision primarily "is accompanied by a presumption of legitimacy that justifies its issuance and its integrity from defects" (Ruling 
of the Supreme Administrative Court, No. 275/2015, 12/16/2015.), but if it is not so, then the court issues a ruling to cancel the contested administrative decision.

Commenting on the cabinet decision issued on April 16, 2020, which includes stopping the bonuses and overtime for all employees, whose total salaries exceed (1300) dinars, stopping the monthly transportation allowance for all employees working in the ministries, and stopping the increase specified for the employees of the government and military agencies for the year 2020, from the date of May 1, 2020 to Dec. 13, 2020, on the pretext of the exceptional circumstances that the Kingdom is going through due to the Corona virus epidemic, and to support efforts to meet these conditions, it is clear to us that this decision was not issued based on the defense law that aims to confront the Corona pandemic and preserve public health. Also it was not issued based on any legal rule. The civil service regulation was amended on April 19,2020, which is a later date to the decision, so the text of Article (191) included exceptional legal rules. So it states that: "A. Notwithstanding what is stated in this regulation or any other legislation: 1 - The Cabinet may, in exceptional and emergency circumstances, decide to suspend, postpone, amend or deduct any part of public employees' salaries, bonuses, allowances, incentives, or any allowances they receive for the periods it deems appropriate, provided that this decision is reconsidered when the exceptional circumstances cease to exist". (Regulation No. (46) of 2020, as amended by the civil service regulation)". This text is unconstitutional and illegal, and has a clear attack on the provisions of Article (124) of the constitution that indicates that, if the defense law is in effect, the authority to take measures to face the exceptional circumstance including in which the regular laws are suspended - it is vested in the person determined by the defense law. The law has specified in Article (3) this person as Prime Minister, who has the right to issue defense orders based on the defense law to face the exceptional circumstance currently represented in the Corona pandemic.

As a result, this decision is considered legally non-existent, that is, it is a material act that not amounts to the administrative decision, as it is flawed with the defect of gross lack of competence for being issued from a noncompetent authority. The theory of the actual employee cannot be invoked here, because it assumes the absence of public authorities and the impossibility of performing their functions (Ibrahim Shiha, 1994).

This assumption is not currently available. The decision is flawed with the defect of violating the law, because it represents a grave breach of the provisions of the Constitution, in addition to that it violates peremptory legal texts, represents a blatant attack on the provisions of the Constitution and the principle of legality, and violates the rule of legislative progression.

It is worth noting that the Administrative Court is currently considering the legitimacy of this decision.

Among the judicial rulings in this field is the ruling of the Supreme Administrative Court, which ruled: "The nonexisting decision is the decision in which there is a flagrant and grave breach of the law, with the decision losing its foundations and its existence and leaving the circle of the application of general provisions of administrative decisions (Judgment No. 25/2015, 3/3/2015).

\section{Results \& Conclusion}

After we have finished this study, we will summarize the results that have been reached. The most important recommendations that we reached, as follows:

- The state, as a public legal person, cannot express its will to satisfy public needs and achieve public benefit except through its employees, because they are its effective tool in providing public services to citizens.

- The legislator organized public affairs through multiple job systems. He did not set a comprehensive definition for the public employee, and he merely showed the respondents to its provisions, and implicitly stipulated that the employee's relationship with the administration is an organizational relationship governed by laws and regulations.

- The salary and its extensions occupy a prominent position in the field of public employment for being the most important right of the public employee, and constitute a major source of income and material incentive urging him to perfect his work. In addition, they are a means of effective management to raise the level of the administrative apparatus and ensure the proper functioning of the public facility.

- There are different types of salary: The basic salary, the gross base, and the total. The minimum salary is embodied in the gross basic salary that combines the basic employee's salary specified in the salary schedule and the high cost of living, while the total salary is the employee's salary plus all the allowances stipulated in the legal system to which the public employee is subject.

- Salary extensions are the job allowances, such as overtime work, representation and bonuses, and are similar to bonuses that they do not become a right of the employee unless by a decision from the competent authority if he fulfills its conditions. 
- The organizational relationship allows the administration to amend the legal position of the public employee, including the reduction of his salary and extensions according to public interest reasons, but under certain conditions.

- The legislator is keen to provide guarantees to the employee, which is not to be deprived of the salary in whole or in part, especially if he stops performing the work for reasons beyond his control. It also allowed him to appeal to cancel defective administrative decisions issued by the administration.

- The Corona pandemic led to negative economic effects on the Jordanian economy, so the cabinet resorted to issuing a decision to stop the annual increases for employees and some of their allowances. It amended the civil service regulation by adding exceptional legal rules for it, but this decision is illegal for violation of the provisions of the Constitution and the rule of legislative progression, and because it was issued in light of the validity of the defense law, which is an exceptional law aimed at confronting the Corona pandemic. This law works to disrupt the normal legal rules, and specifically gives the Prime Minister the power to take measures to confront the exceptional circumstance and to invoke his exceptional legal rules.

\section{Recommendations}

- We recommend that the legislator regulate public affairs by law not by regulation, and include the cost of living allowance within the basic salary scale for all categories of employees for being an integral part of the minimum salary, with the need to raise the minimum salary to ensure decent living for employees.

- We propose to the legislator to abolish the salary deduction penalty, as a disciplinary punishment that is imposed on the employee, and to make do with other penalties, given that the salary is a major source of income for the employee and his family.

- In order to protect the employee's right to salary and its extensions. In defense of the principle of legality, we call on the legislator to cancel the amendment of Article (193) of the Civil Service Law; This is in line with the rule of legislative progression, as it contradicts the defense law, and constitutes a violation of the constitutional provisions. At the same time, we appeal to the Cabinet to withdraw its decision related to facing the Corona pandemic, which includes stopping the annual increases and some of the allowances due to employees, because the decision is nonexistent and may be withdrawn without an appointment.

\section{References}

Abdul, H. H. (1974). Studies in the Public Function in the French System. Modern Cairo Library, Cairo.

Ahmad, A.-S. (2005). Promotion of the Public Official in Qatar. Dar Al-Nahda Al-Arabia, Cairo.

Ahmad, S. A.-D. (1983). The Legal System of a Public Official in the Republic of Yemen, Ph.D., Cairo.

Alain, P. (1971). Traité pratique de la fonction publique. L. G. D. J, Paris.

Al-Nada, H. (1972). The Administrative Judiciary in Jordan. The Association of Printing Workers, Amma.

André, de L. (1953). Traité élémantaire de droit administratif(1st ed.). L. G. D.J. Paris.

André, de L. (1982). Manuel de droit administratif. Paris.

André, de L., \& Yves, G. (n.d.). Traite de Droit Administratif(12th ed.) L.G.D.J.

Anis, J. (2007). The Public Job. Arab Renaissance House, Cairo.

Anwar, R. (1997). Administrative Law. Arab Renaissance House, Cairo.

Asim, A. (1980). Obedience in the Public Service, Ph.D., Cairo University.

Badria, A.-S. (1994). The Legal System of Public Employee Rights has evolved in accordance with the general job legislation in Kuwait. Law magazine.

Cornu (G). (1951). Etude comparé de la responsabilité délictuelle en droit privé et en droit pubic. Paris.

Esmat, E.-S. (1999). The legal nature of the promotion between right and duty. Arab Renaissance House, Cairo.

General Employment Law, No. 16/84, issued on 11/1/1984.

Gustave, P. (2002). Droit administratif de la fonction publique (16th ed.). Dalloz.

Hamada, S. (1977). The Legal System of Wages and Salaries in the Public Job, PhD Thesis, Ain Shams University, Cairo.

Ibrahim, S. (1994). The Lebanese Administrative Court. Undergraduate House, Beirut.

Mahmoud, H. (1998). Disciplinary Theory in the Public Service. Al-Iman Press, Cairo. 
Majed, E.-H. (2006). Administrative Law. New University House, Alexandria.

Mohamed, E.-D. (2006). Administrative Protection of the Public Employee. Arab Renaissance House, Cairo.

Mohamed, H. (1997). The Constitutional Protection of the Public Official. Al-Ahram Press, Cairo.

Mohsen, A. (1997). Public Authority Disciplinary Authority, PhD Thesis, Ain Shams University.

Muhammad, A. Y. (1999). Selection on the basis of validity for the public position in the Islamic administrative system. New University House, Alexandria.

Muhammad, A.-K. (2017). Administrative Law. Dar Al-Thaqafa, Amman.

Muhammad, K. (2002). Public Employee Rights and Freedoms, PhD Thesis, Beirut Arab University.

Naeem, A. (1971). Contraindications to Promotion. The Journal of Editing Governmental Issues, 15(3).

Nawaf, K. (2019). Administrative Law. Zamzam Press, Amman.

Omar, H. (1994). Wages and their Role in Motivating the Public Employee. University Culture House, Cairo.

Piquemal, V. M. (1973). Le foncitonnaire Droit et garanties édition Berger. Levrauit, Paris.

Plantey. (2001). La fonction publique traite général (2nd ed.). Paris.

Ramadan, B. (1997). Introduction in Administrative Law. Arab Renaissance House, Cairo.

Rolland. (1953). Précis droit administratif. Paris.

Serge, S. (2006). Code de la Foncion publique, dalloz.

Sherif, K. (2007). The Public Job. Arab Renaissance House, Cairo.

Suleiman, A.-T. (1992). Al-Wajeez in Administrative Law. Dar Al-Fikr Al-Arabi, Cairo.

Suleiman, B. (2017). The Public Service. House of Culture, Amman.

Waline (Marcel). (1959). Droit administratif (8th ed.). Paris. https://doi.org/10.2307/837731

\section{Copyrights}

Copyright for this article is retained by the author(s), with first publication rights granted to the journal.

This is an open-access article distributed under the terms and conditions of the Creative Commons Attribution license (http://creativecommons.org/licenses/by/4.0/). 